\title{
PENGARUH PENAMBAHAN ARANG TEMPURUNG KELAPA DAN BOKASHI PUPUK KANDANG TERHADAP PERTUMBUHAN SEMAI AKASIA (Acacia mangium Willd.) DI MEDIA BEKAS TAMBANG KAPUR
}

\author{
Application of Coconut Shells Charcoal and Cow Feces (Bokashi) on the Growth of Acacia \\ (Acacia mangium Willd.) at the Postmining Limestone Soil
}

\author{
Basuki Wasis $^{1^{*}}$ dan Sarah Eranissa Islamika ${ }^{2}$
}

(Diterima Februari 2019/Maret 2019)

\begin{abstract}
Continuous mining activities of limestone operation may cause negative impact such as environmental damage and reduction of soil quality (physically, chemistry, or biological). Revegetation is the process to increasing productivity of postmining limestose land. Acacia mangium is one of fast growing species that can grow in marginal land, symbitotic with rhizobium bacteria, and high economic value. The purpose of this research are to test the response of coconut shell charcoal and cow feces (bokashi) addition to the growth of akasia (Acacia mangium) seedling on postmining limestone soil and to find out the optimum dose of coconut shell charcoal and cow feces (bokashi) addition. This research used a complete randomized design factorial with two factors, each factor have four degree. First factor is addition of coconut shell charcoal and second factors is addition of cow feces (bokashi). The result of this research showed that coconut shell charcoal and cow feces (bokashi) addition on postmining limestone soil gives positive influence towards the amount of root nodule. But not affect other parameters such as height, diameter, total wet weight, total dry weight, and root tops ratio. The interaction between addition $10 \mathrm{~g}$ of coconut shell charcoal and $20 \mathrm{~g}$ of cow feces (bokashi) is the best composition for a significant effect in improving the amount of root nodule of A. mangium seedling by $78.58 \%$. Very high levels of Ca in the soil medium will be toxic to the acacia plant.
\end{abstract}

Key words: Acacia mangium, bokashi cow feces, coconut shell charcoal, limestone mining

\section{PENDAHULUAN}

Konversi lahan hutan untuk kegiatan pertambangan dapat menghambat fungsi hutan sebagai sumber kehidupan. Batu kapur merupakan salah satu bahan galian tambang yang dapat dimanfaatkan menjadi bahan baku semen. Kegiatan pertambangan batu kapur masih aktif dilaksanakan di Ciampea, Bogor, Jawa Barat. Proses penambangan batu kapur terdiri dari kegiatan pembukaan wilayah hutan, pengeboran batuan untuk mengancurkan material batu kapur, pengangkutan hasil tambang, pembakaran batuan, dan pemasaran kapur mentah. Alat berat yang digunakan dalam kegiatan pertambangan untuk membuka wilayah hutan dan mengeluarkan barang tambang didalam perut bumi mengakibatkan perubahan topografi, vegetasi hutan hilang, lapisan top soil hilang, kandungan unsur hara penting dan bahan organik menurun, kepadatan tanah tinggi, $\mathrm{pH}$ tinggi, suhu tanah tinggi, dan keanekaragaman mikroba tanah menurun (Prayudyaningsih 2014, Putra et al. 2017, Setiadi dan Adinda 2013, Wasis et al. 2019)

\footnotetext{
${ }^{1}$ Staff Pengajar Dept. Silvikultur, Fakultas Kehutanan IPB

* Penulis korespondensi: e-mail: basuki_wasis@yahoo.com

${ }^{2}$ Mahasiswa Dept. Silvikultur, Fakultas Kehutanan IPB
}

Upaya pengendalian yang dapat dilakukan untuk meningkatkan produktivitas lahan pasca tambang adalah kegiatan revegetasi. Perusahaan yang mengeksploitasi hasil tambang harus bertanggung jawab untuk melakukan kegiatan tersebut.. Revegetasi merupakan upaya kegiatan penanaman kembali pada lahan pasca tambang dengan tujuan meningkatkan produktivitas lahan, meninimalisir erosi, mengembalikan biodiversitas, dan memperbaiki iklim mikro sehingga kawasan hutan dapat berfungsi sesuai peruntukannya (Istomo et al. 2015, Wasis dan Fathia 2011).

Kegiatan revegetasi dilakukan pada lahan bekas tambang kapur yang memiliki $\mathrm{pH}$ dan kandungan $\mathrm{Ca}$ yang tinggi sehingga perlu dilakukan pemilihan jenis yang tepat. Akasia (Acacia mangium Willd.) merupakan jenis legum cepat tumbuh yang mampu bersimbiosis dengan bakteri rhizobium, dapat tumbuh pada kondisi lingkungan kurang subur yang miskin hara, dapat beradaptasi dengan lingkungan tanah masam, dan memiliki keunggulan sebagai bahan baku pulp, serta relatif tahan terhadap hama dan penyakit (Kartikaningtyas et al. 2017). Dalam meningkatkan keberhasilan pertumbuhan tanaman, maka diperlukan pemberian pupuk pada media tumbuh. Tujuan penelitian adalah mengamati penambahan arang tempurung kelapa dan bokashi pupuk kandang pada lahan bekas tambang kapur terhadap pertumbuhan tanaman akasia. 


\section{METODE PENELITIAN}

\section{Waktu dan Tempat Penelitian}

Penelitian dilaksanakan mulai bulan Maret sampai Juli 2017 di rumah kaca Bagian Ekologi Hutan Departemen Silvikultur Fakultas Kehutanan IPB, Laboratorium Pengaruh Hutan Departemen Silvikultur Fakultas Kehutanan IPB. Sampel media tanaman berasal dari lokasi tambang di Kecamatan Ciampea, Kabupaten Bogor, Jawa Barat, sedangkan analisis hara tanah di Laboratorium Departemen Ilmu Tanah dan Sumberdaya Lahan Fakultas Pertanian IPB.

\section{Alat dan Bahan}

Alat-alat yang digunakan dalam penelitian ini adalah timbangan (neraca analitik), cangkul, sekop kecil, alat penyiram, mistar, kaliper, timbangan digital, kamera, alat tulis, alat hitung (kalkulator), polybag dengan ukuran $20 \mathrm{~cm} \times 20 \mathrm{~cm}$, tallysheet, software Microsoft excel 2007 dan SAS versi 9 portable. Sedangkan, bahan yang digunakan dalam penelitian ini adalah bibit $A$. mangium yang berumur 3 bulan, arang tempurung kelapa, bokashi pupuk kandang, pupuk kompos, insektisida, dan media tanam berupa tanah bekas penambangan kapur.

\section{Prosedur Penelitian}

Pelaksanaan penelitian ini terdiri dari beberapa tahapan, yaitu persiapan, penyapihan, pemeliharaan, pengamatan dan pengambilan data, serta rancangan percobaan dan analisis data.

\section{Persiapan}

Tahap persiapan meliputi penyiapan media tanam dan bibit akasia. Media tanam yang digunakan merupakan limbah tambang kapur. Limbah tambang kapur tersebut ditimbang seberat $1 \mathrm{~kg}$ dalam keadaan kering udara dan dicampurkan dengan arang tempurung kelapa dan bokashi pupuk kandang yang komposisinya sesuai dengan perlakuan yang diujicobakan. Arang tempurung kelapa komposisi takarannya, masingmasing adalah $0 \mathrm{~g} /$ polybag (kontrol), $10 \mathrm{~g} /$ polybag, 20 $\mathrm{g} /$ polybag, dan $30 \mathrm{~g} /$ polybag. Sementara untuk bahan arang tempurung kelapa komposisi takarannya, masingmasing adalah $0 \mathrm{~g} /$ polybag (kontrol), $20 \mathrm{~g} /$ polybag, 40 $\mathrm{g} /$ polybag, dan $60 \mathrm{~g} /$ polybag. Bibit yang digunakan adalah semai akasia yang berumur 3 bulan, memiliki tinggi dan diameter yang relatif sama, serta bebas dari hama dan penyakit.

\section{Penyapihan}

Bibit akasia yang berumur 3 bulan dipindahkan ke dalam media yang telah dipersiapkan. Pemindahan bibit ini dilakukan pada waktu sore hari dengan tujuan untuk mengurangi terjadinya penguapan pada semai akasia.

\section{Pemeliharaan}

Pemeliharaan bibit akasia meliputi penyiraman sebanyak dua kali sehari, yaitu pagi dan sore hari. Penyiraman dilakukan dengan mempertimbangkan kondisi media tanam di dalam polybag. Pemupukan dengan menambahkan 50g kompos pada seluruh perlakuan. Pengendalian hama dan penyakit dengan menyemprotkan fungisida pada semai akasia.

\section{Pengamatan dan Pengambilan Data}

Parameter yang diukur adalah tinggi, diameter, berat kering total, jumlah bintil akar dan analisis unsur hara. Pengukuran tinggi semai sengon dilakukan dengan menggunakan mistar dari pangkal batang yang telah ditandai dengan cat $(1 \mathrm{~cm}$ diatas media) sampai titik tumbuh pucuk apikal. Pengukuran diameter semai sengon dilakukan dengan menggunakan caliper digital. Berat basah total diukur pada akhir pengamatan. Semai akasia dipanen kemudian dipisahkan bagian akar dan pucuk lalu ditimbang dengan menggunakan timbangan. Berat basah total merupakan penjumlahan antara berat basah akar dengan berat basah pucuk. Berat kering diukur setelah bagian tanaman dikeringkan dalam oven pada suhu $80^{\circ} \mathrm{C}$ selama 24 jam, kemudian bagian akar dan pucuk tanaman yang telah dioven ditimbang. Berat kering total diperoleh dengan menjumlahkan berat kering akar dengan berat kering pucuk. Jumlah bintil akar diukur dengan memisahkan bintil akar dengan akarnya kemudian dihitung jumlahnya. Nisbah pucuk akar (NPA) dihitung berdasarkan perbandingan nilai berat kering total pucuk dengan nilai kering total akar. Analisis unsur hara dilakukan pada akhir pengamatan. Sample yang diambil sebanyak 2 (dua) sampel yaitu kontrol, perlakuan yang memiliki pertumbuhan terbaik.

\section{Rancangan Percobaan dan Analisis Data}

Rancangan percobaan yang digunakan adalah rancangan faktorial dengan desain Acak Lengkap dengan dua faktor (Sastrosupadi 2000). Faktor pertama yaitu pupuk arang yang terdiri dari 4 taraf (A0: $0 \mathrm{~g}$, A1 : $10 \mathrm{~g}, \mathrm{~A} 2: 10 \mathrm{~g}$ dan A3 : $30 \mathrm{~g}$ ), faktor kedua yaitu bokashi pupuk kandang yang terdiri dari 4 taraf (B0 : 0 $\mathrm{g}, \mathrm{B} 1: 20 \mathrm{~g}, \mathrm{~B} 2: 40 \mathrm{~g}$ dan B3: 60g).

Tabel 1 Rekapitulasi hasil sidik ragam pengaruh perlakuan arang tempurung kelapa dan bokashi pupuk kandang terhadap pertumbuhan bibit akasia

\begin{tabular}{lccc}
\hline & \multicolumn{3}{c}{ Perlakuan } \\
\cline { 2 - 4 } Parameter & $\begin{array}{c}\text { Arang Tempurung } \\
\text { Kelapa }\end{array}$ & Bokashi Pupuk Kandang & $\begin{array}{c}\text { Arang Tempurung Kelapa x } \\
\text { Bokashi Pupuk Kandang }\end{array}$ \\
\hline Tinggi & $0.2167 \mathrm{tn}$ & $0.4216 \mathrm{tn}$ & $0.4803 \mathrm{tn}$ \\
Diameter & $0.5150 \mathrm{tn}$ & $0.4700 \mathrm{tn}$ & $0.2457 \mathrm{tn}$ \\
Berat Basah Total & $0.0976 \mathrm{tn}$ & $0.2691 \mathrm{tn}$ & $0.2752 \mathrm{tn}$ \\
Berat Kering Total & $0.1915 \mathrm{tn}$ & $0.1306 \mathrm{tn}$ & $0.2059 \mathrm{tn}$ \\
Nisbah Pucuk Akar & $0.5314 \mathrm{tn}$ & $0.3399 \mathrm{tn}$ & $0.1954 \mathrm{tn}$ \\
Jumlah Bintil Akar & $0.7366 \mathrm{tn}$ & $0.5898 \mathrm{tn}$ & $0.0271^{*}$ \\
\hline
\end{tabular}

$*=$ perlakuan berpengaruh nyata pada selang kepercayaan $95 \% \mathrm{tn}=$ perlakuan tidak berpengaruh nyata 
Data yang diperoleh berdasarkan pengamatan dan pengukuran, kemudian dianalisis dengan menggunakan model linier. Data diolah menggunakan software SAS 9.1, Nilai P-value $<\alpha(0,05)$, maka perlakuan memberikan pengaruh nyata terhadap tinggi, diameter, berat basah total, berat kering total, jumlah bintil akar, dan NPA, kemudian dilanjutkan dengan uji lanjut Duncan's Multiple Range Test.

\section{HASIL DAN PEMBAHASAN}

\section{Pertumbuhan Tanaman}

Berdasarkan Tabel 1, hasil sidik ragam menunjukkan bahwa perlakuan penambahan arang tempurung kelapa tunggal tidak berpengaruh nyata pada semua parameter yang diamati. Penambahan bokashi pupuk kandang juga tidak berpengaruh nyata pada semua parameter yang diamati. Sedangkan interaksi antara pemberian arang tempurung kelapa dan bokashi pupuk kandang hanya berpengaruh nyata pada parameter jumlah bintil akar.

Hasil penelitian menunjukkan bahwa perlakuan A1B1 (arang tempurung kelapa $10 \mathrm{~g}+$ bokashi pupuk kandang $20 \mathrm{~g}$ ) menempati posisi teratas dengan nilai akhir pertumbuhan tinggi paling besar yaitu $16.30 \mathrm{~cm}$. Penambahan arang tempurung kelapa dan bokashi pupuk kandang berfungsi untuk mengoptimalisasi pertumbuhan bibit akasia pada media bekas tambang kapur. Menurut Faizin et al. (2015), pertumbuhan tanaman yang optimal dipengaruhi oleh media tanam yang tepat. Hal ini menunjukkan bahwa media tanam dengan penambahan arang tempurung kelapa $10 \mathrm{~g}$ dan bokashi pupuk kandang $20 \mathrm{~g}$ dapat memberikan pengaruh positif untuk ketersediaan unsur hara pada tanah bekas tambang kapur dan mampu meningkatkan pertumbuhan bibit akasia dibandingkan dengan perlakuan dosis yang lain. Menurut Muhajir et al. (2015), penyediaan unsur hara untuk tanaman dapat melalui penambahan bahan organik pada media tanam untuk meningkatkan pertumbuhan bibit unggul.

Penambahan arang tempurung kelapa dan bokashi pupuk kandang dengan dosis yang berbeda tidak menimbulkan respon yang berbeda pada laju pertumbuhan tinggi bibit akasia. Hal ini diduga karena peningkatan dosis yang semakin besar tidak selalu diikuti oleh pertumbuhan tanaman yang semakin baik. Pemberian dosis pupuk dalam jumlah sedikit tidak memberikan pengaruh yang signifikan pada tanaman, namun pemberian dosis yang besar dapat menyebabkan ketersediaan nitrogen dan fosfor yang berlebihan dalam tanah yang mampu memicu keracunan tanaman (Anayansi et al. 2013; Prasetya et al. 2009). Sedangkan penelitian Istantini (2012), menunjukkan penambahan arang tempurung kelapa dan bokashi pupuk kandang pada media bekas tambang emas berpengaruh nyata terhadap pertumbuhan tinggi semai jabon.

Penambahan arang tempurung, bokashi pupuk kandang, dan interaksi antara keduanya tidak memberikan pengaruh nyata terhadap pertumbuhan diameter bibit akasia. Hal ini diduga karena pertumbuhan tinggi bibit akasia lebih dominan daripada pertumbuhan diameter bibit akasia, dan kesuburan tanah yang rendah. Pertumbuhan diameter adalah pertumbuhan sekunder tanaman, diameter akan bertambah secara signifikan apabila tanaman sudah dewasa dan pertumbuhan primer (tinggi) nya sudah tidak dominan (Winata 2014).

Pendugaan lainnya dikarenakan tingginya kandungan unsur $\mathrm{Ca}$ dalam tanah yang berdampak pada tingginya nilai $\mathrm{pH}$ tanah tambang kapur dan timbulnya keracunan (toksik). Menurut Giel dan Bojarczuk (2011), tinggi kandungan unsur $\mathrm{Ca}$ dalam tanah dapat menghambat pertumbuhan suatu tanaman. Menurut Muharam dan Saefudin (2016), pH tanah yang tinggi akan menyebabkan tanaman tubuh kerdil dan menguning. Gejala tanaman tumbuh kerdil dan menguning dapat pula diakibatkan defisiensi unsur hara N (Fahmi et al. 2010).

Hasil sidik ragam menunjukkan bahwa penambahan arang tempurung kelapa tunggal dan bokashi pupuk kandang tunggal tidak berpengaruh nyata terhadap jumlah bintil akar pada bibit. Sedangkan interaksi dari penambahan arang tempurung kelapa dan bokashi pupuk kandang berpengaruh nyata Hasil uji Duncan pengaruh interaksi arang tempurung kelapa dan bokashi pupuk kandang tersedia pada Tabel 2 .

Berdasarkan hasil uji lanjut Duncan's Multiple Range Test, dapat diketahui bahwa perlakuan A1B1 (arang tempurung kelapa $10 \mathrm{~g}+$ bokashi pupuk kandang 20g) memberikan pengaruh terbaik pada jumlah bintil akar dengan peningkatan terhadap kontrol sebesar 78.5814\%. Hal ini menandakan bahwa perlakuan A1B1 dapat meningkatkan pembentukan bintil akar bibit akasia yang ditanam di media bekas tambang kapur.

Respon pembentukan bintil akar terendah

Tabel 2 Uji Duncan pengaruh arang tempurung kelapa dan bokashi pupuk kandang terhadap jumlah bintil akar (JBA) semai akasia

\begin{tabular}{ccc}
\hline Perlakuan & $\begin{array}{c}\text { Rata-rata jumlah } \\
\text { bintil akar }\end{array}$ & $\begin{array}{c}\text { Persentase } \\
\text { peningkatan }(\%)\end{array}$ \\
\hline A1B1 & $16.6670 \mathrm{a}$ & 78,5814 \\
A0B3 & $14.6670 \mathrm{ab}$ & 57,1520 \\
A0B2 & $14.3330 \mathrm{ab}$ & 53,5733 \\
A2B0 & $13.0000 \mathrm{abc}$ & 39,2907 \\
A3B3 & $12.6670 \mathrm{abc}$ & 35,7227 \\
A2B1 & $11.0000 \mathrm{abc}$ & 17,8614 \\
A3B0 & $9.3330 \mathrm{abc}$ & 0,0000 \\
A0B0 & $9.3333 \mathrm{abc}$ & 0,0000 \\
A1B3 & 8.6670abc & $-7,1360$ \\
A3B2 & 7.3330abc & $-21,4293$ \\
A1B0 & 7.3330abc & $-21,4293$ \\
A2B3 & 6.6670abc & $-28,5653$ \\
A3B1 & 6.3330bc & $-32,1440$ \\
\hline
\end{tabular}

Keterangan: Angka yang diikuti oleh huruf yang sama menunjukkan perlakuan tidak berbeda nyata pada selang kepercayaan $95 \%$. 
ditunjukkan oleh perlakuan A3B1 (arang tempurung kelapa 30g + bokashi pupuk kandang 20g) dengan peningkatan terhadap kontrol sebesar $-32.1440 \%$. Hal ini menunjukkan bahwa pemberian perlakuan A3B1 memberikan respon negatif terhadap jumlah bintil akar. Respon negatif ini diduga karena perlakuan A3B1 tidak mendukung terhadap ketersediaan unsur hara untuk mendukung pertumbuhan bakteri rhizobium (Adrialin $e t$ al. 2014).

Akasia merupakan salah satu tanaman legum yang dapat bersimbiosis dengan bakteri rhizobium. Simbiosis antara tanaman legum dan bakteri rhizobium dapat menambat nitrogen diudara sehingga tersedia untuk tanaman dan dapat tumbuh dengan cepat pada tanah yang miskin unsur nitrogen (Diouf et al. 2003). Bintil akar merupakan hasil simbiosis antara akar tanaman dengan bakteri rhizobium. Setelah akar utama membentuk rambut akar atau cabang akar maka akan terbentuk bintil akar yang berfungsi untuk meningkatkan pertumbuhan tanaman (Kumalasari et al. 2013). Pada $\mathrm{pH}$ yang terlalu masam <4,3 bakteri rhizobium tidak dapat hidup (Lubis et al. 2015).

Hasil sidik ragam menunjukkan bahwa penambahan arang tempurung kelapa tunggal, bokashi pupuk kandang tunggal maupun interaksi pemberian kedua perlakuan tersebut tidak berpengaruh nyata terhadap nilai nisbah pucuk akar bibit akasia. Rata-rata nisbah pucuk akar bibit akasia dapat dilihat pada Gambar 1 .

Nisbah pucuk akar (NPA) merupakan perbandingan antara nilai biomassa pucuk dan biomassa akar tanaman. Nilai NPA yang baik adalah antara $1-3$, namun semakin

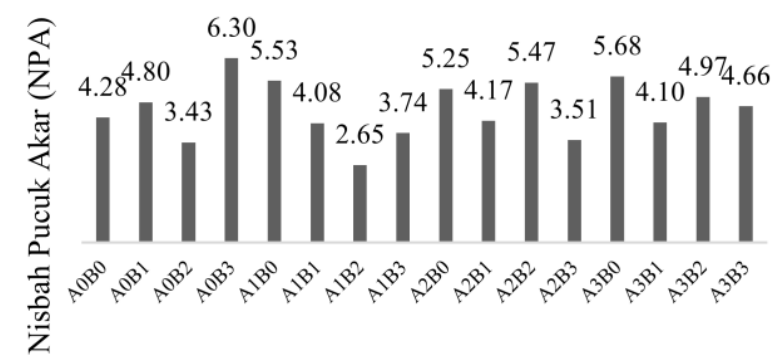

Perlakuan penambahan arang tempurung kelapa dan bokashi pupuk kandang

Gambar 1 Rata-rata nilai nisbah pucuk akar (NPA) bibit akasia dengan berbagai perlakuan penambahan arang tempurung kelapa dan bokashi pupuk kandang mendekati nilai minimum 1 maka pertumbuhan dan kemampuan hidup tanaman menunjukkan nilai terbaik. Hal ini berarti perlakuan A1B2 (arang tempurung kelapa $10 \mathrm{~g}+$ bokashi pupuk kandang $40 \mathrm{~g}$ ) memiliki biomassa akar yang lebih tinggi dibandingkan biomassa pucuk. Ketahanan dan kemampuan hidup semai A1B2 baik karena memiliki perakaran yang baik, namun perlu diamati keseimbangan antara kemampuan akar menyerap unsur hara dan kemampuan tunas menjalankan proses fotosintesis dan transpirasi (Wasis dan Istantini 2013).

Nisbah pucuk akar merupakan faktor penting yang dapat menentukan kualitas bibit suatu tanaman karena menggambarkan kemampuan tanaman menyerap air dan mineral dengan melakukan proses transpirasi dan fotosintesis (Fitriani dan Haryanti 2016). Selain itu, parameter nisbah pucuk akar juga dapat menjadi indikator ketahanan tanaman untuk ditanam dilapang. Pertumbuhan akar dalam jumlah banyak dan memanjang dapat mengoptimalisasi penyerapan hara dan air dalam tanah, penyerapan air yang meningkat akan digunakan tanaman untuk proses fotosintesis dan penyebaran fotosintat ke semua bagian tanaman (Fitriani dan Haryanti 2016).

Berdasarkan grafik yang tersedia pada Gambar 1, perlakuan selain A1B2 memiliki rentang nilai 3.43-6.30. Nilai ini cukup besar jika dibandingan dengan literatur yang menunjukkan bahwa nilai NPA yg baik antara 1-3. Nilai NPA terbesar ada pada perlakuan A0B3 (arang tempurung kelapa $0 \mathrm{~g}+$ bokashi pupuk kandang 60g) yaitu 6.30. Semai akasia dengan nilai nisbah pucuk akar

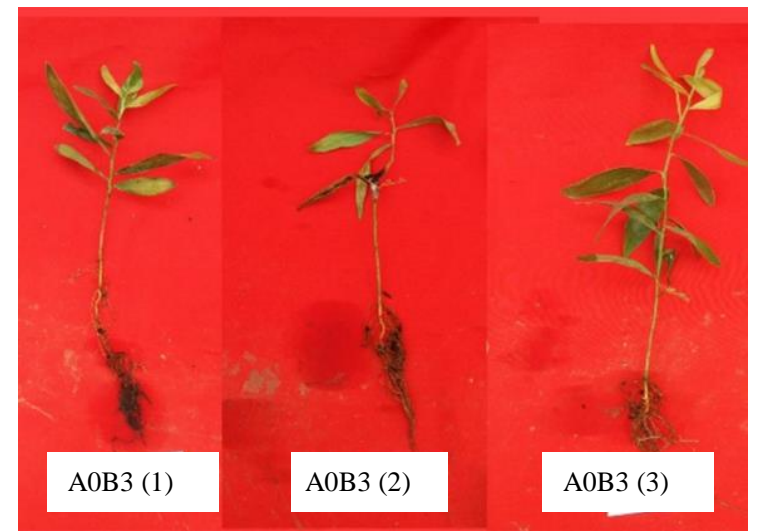

Gambar 2 Bibit akasia perlakuan A0B3 yang memiliki nilai nisbah pucuk akar tertinggi

Tabel 3 Hasil analisis tanah pada perlakuan kontrol dan A1B1

\begin{tabular}{lccccc}
\hline Sifat Tanah & Kontrol & Kriteria & A1B1 & Kriteria & Perubahan \\
\hline pH & 7.42 & Netral & 7.07 & Netral & $-0,35$ \\
KTK $(\mathrm{me} / 100 \mathrm{~g})$ & 36.01 & Tinggi & 36.06 & Tinggi & $+0,05$ \\
C-Organik $(\%)$ & 0.82 & Sangat Rendah & 4.06 & Tinggi & $+3,24$ \\
N-Total $(\%)$ & 0.08 & Sangat Rendah & 0.25 & Sedang & $+0,17$ \\
P Bray I $(\mathrm{ppm})$ & 120.03 & Sangat Tinggi & 199.89 & Sangat Tinggi & $+79,86$ \\
Ca $(\mathrm{me} / 100 \mathrm{~g})$ & 78.27 & Sangat Tinggi & 73.66 & Sangat Tinggi & $-4,61$ \\
$\mathrm{Mg}(\mathrm{me} / 100 \mathrm{~g})$ & 2.36 & Tinggi & 4.20 & Tinggi & $+1,84$ \\
$\mathrm{~K}(\mathrm{me} / 100 \mathrm{~g})$ & 0.83 & Tinggi & 2.44 & Sangat Tinggi & $+1,61$ \\
$\mathrm{Na}(\mathrm{me} / \mathrm{l00g})$ & 0.86 & Tinggi & 1.83 & Sangat Tinggi & $+0,97$ \\
\hline
\end{tabular}

Keterangan: Kriteria penilaian sifat kimia tanah (Lembaga Penelitian Tanah 1983) 
yang tinggi menunjukkan bahwa pertumbuhan pucuk tanaman lebih tinggi dibandingan dengan pertumbuhan akar tanaman. Hal ini ini diduga karena ketersedian air dan unsur hara untuk tanaman tersedia secara optimal, sehingga pertumbuhan akar akan kalah dominan dibandingkan dengan pertumbuhan tinggi (Hardjowigeno 2003; Wasis dan Andika 2017).

\section{Analisis Tanah}

Penambahan arang dan bokashi menurunkan $\mathrm{pH}$ tanah sebesar 0,35. Pada perlakuan A1B1 memiliki pH tanah sebesar 7.07 (netral). Penambahan arang tempurung kelapa dan bokashi pupuk kandang telah dapat memperbaiki pH tanah (Tabel 3). Menurut Razaq et al. (2017), penambahan pupuk atau bahan organik dapat memodifikasi nilai $\mathrm{pH}$ tanah. Unsur hara dalam tanah akan lebih mudah diserap oleh tanaman pada keadaan $\mathrm{pH}$ tanah netral (Arisandy et al. 2012; Hardjowigeno 2003).

Hasil analisis tanah menunjukkan bahwa tanah pemberian arang dan bokashi menigkatkan $\mathrm{C}$ organik tanah sebesar 3,24. C-organik merupakan bahan organik yang memiliki peran penting terhadap ketersediaan unsur esensial seperti N, P dan K dan dapat meningkatkan aktivitas mikroorganisme untuk proses dekomposisi tanah (Hardjowigeno 2003).

Hasil uji laboratorium menunjukkan bahwa kandungan unsur hara makro $\mathrm{N}, \mathrm{P}, \mathrm{K}$ dan $\mathrm{Mg}$ pada tanah yang diberi perlakuan penambahan arang tempurung kelapa dan bokashi pupuk kandang mengalami peningkatan dibandingan dengan tanah control untuk $\mathrm{N}$ sebesar $0,17 \%$, P sebesar 79,86 ppm, $\mathrm{K}$ sebesar 1,61 me/100 g, dan Mg sebesar 1,84 me/100 g. Hal ini menunjukkan bahwa pemberian arang tempurung kelapa dan bokashi pupuk kandang dapat meningkatkan ketersediaan unsur hara pada tanah bekas tambang kapur. Menurut Yuliana et al. (2015), bokashi akan lebih cepat menyediakan unsur hara dan bahan organik untuk tanaman karena pembuatannya menggunakan teknologi EM-4 sehingga pupuk organik cepat terdekomposisi.

Kalsium (Ca) merupakan unsur hara makro sekunder yang dibutuhkan tanaman dan berfungsi sebagai penyusun dinding sel tanaman dan pembelahan sel (Hardjowigeno 2003). Hasil analisis laboratorium menunjukkan bahwa kandungan Kalsium (Ca) pada tanah bekas tambang kapur kontrol sanggat tinggi (78.27 me/100g). Kandungan Kalsium (Ca) pada tanah bekas tambang kapur yang ditambahkan arang tempurung kelapa dan bokashi pupuk kandang (A1B1) mengalami penurunan menjadi $73.66 \mathrm{me} / 100 \mathrm{~g}$ namun masih dalam kategori sangat tinggi. Penambahan arang tempurung kelapa dan bokashi pupuk kandang tidak berpengaruh secara signifikan terhadap penurunan kandung unsur hara $\mathrm{Ca}$. Tingginya kandungan unsur hara $\mathrm{Ca}$ dalam tanah bekas tambang kapur diduga dapat menghambat pertumbuhan semai akasia, hal ini dapat dilihat dari pertumbuhan semai akasia yang mengalami gejala menguning selama pertumbuhan. Gejala menguning juga ditunjukkan pada hasil penelitian White and Broadley (2003), terdapat bintik kekuningan di tanaman tomat yg diakibatkan kelebihan kalsium. Hasil penilitian ini menunjukkan bahwa Ca yang sangat tinggi pada media/tanah akas bersifat toksik bagi tanaman., hal ini menjadi salah satu penyebab parameter pada pertumbuhan tanaman akasia yaitu tinggi, diameter, berat basah dan berat kering tidak berpengaruh nyata.

\section{SIMPULAN}

Perlakuan penambahan arang tempurung kelapa tunggal dan penambahan bokashi pupuk kandang tunggal tidak berpengaruh nyata terhadap pertumbuhan tinggi, diameter, berat basah total, berat kering total, nisbah pucuk akar, dan jumlah bintil akar bibit akasia. Penambahan arang tempurung kelapa dan bokashi pupuk kandang pada media bekas tambang dan interaksi keduanya berpengaruh nyata terhadap jumlah bintil akar bibit akasia. Pengaruh interaksi perlakuan A1B1 (arang tempurung kelapa $10 \mathrm{~g}$ + bokashi pupuk kandang $20 \mathrm{~g}$ ) adalah komposisi terbaik untuk penambahan media bekas tambang sebagai media tanam bibit akasia. Perlakuan A1B1 memberikan persentase peningkatan terhadap kontrol sebesar 78.514\%. Kadar Ca yang sangat tinggi pada media tanah akan bersifat toksik bagi tanaman akasia.

\section{DAFTAR PUSTAKA}

Adrialin GS, Wawan, Venita Y. 2014. Produksi biomassa, kadar $\mathrm{N}$ dan bintil akar berbagai leguminoius cover crop (LCO) pada tanah dystrudepts. Jom Faperta 1(4):1-9.

Anayansi C, Fernandez C, Naeth MA, Wilkinson SR. 2013. Antroposol development frome limetone quarry substrates. Can. J. Soil. Sci. 93:555566.doi:10.4141/CJSS2012-120.

Arisandy KR, Herawati EY, Suprayitno E. 2012. Akumulasi logm berat timbal $(\mathrm{Pb})$ dan gambaran histologi pada jaringan Avicennia marina (forsk.) Vierh di perairan pantai jawa timur. Jurnal Penelitian Perikanan 1(1):15-25.

Diouf D, Forester S, Neyra M, Lesueur D. 2003. Optimasation of inoculation of Leucaena leucocephala and Acacia mangium with rhizobium under greenhouse conditions. Ann. For. Sci. 60: 379-384.

Fahmi A, Syamsudin, Utami SNH, Radjagukguk B. 2010. Pengaruh interaksi hara nitrogen dan fosfor terhadap pertumbuhan tanaman jagung (Zea mays L) pada tanah regosol dan latosol. Berita Biologi 10(3):297-304.

Faizin N, Mardhiansyah M, Yoza D. 2015. Respon pemberian beberapa dosis pupuk fosfor terhadap pertumbuhan semai akasia dan ketersediaan fosfor di tanah. JOM Faperta. 2(2):1-9.

Fitriani HP, Haryanti S. 2016. Pengaruh penggunaan pupuk nasosilika terhadap pertumbuhan tanaman tomat (Solanum lycopersicum) var. bulat. Buletin Anatomi dan Fisiologi 24(1):34-41.

Giel P, Bojarczuk K. 2011. Effects of high concetrations of calcium salts in the substrate and its $\mathrm{pH}$ on the growth of selected rhododendron cultivars. 
Acara societatis botanicorum poloniae 80(2):105114.

Hardjowigeno S. 2003. Ilmu Tanah. Jakarta(ID): Akademia Akapressindo.

Istantini A. 2012. Aplikasi arang tempurung kelapa dan kotoran sapi (bokashi) terhadap pertumbuhan semai jabon pada media tanam tailing tambang emas[skripsi]. Bogor(ID): Institut Pertanian Bogor.

Istomo, Setiadi Y, Putri AN. 2015. Evaluasi keberhasilan tanaman hasil revegetasi di lahan pasca tambang batubara site lati PT. Berau Coal Kalimantan Timur. Jurnal Silvikultur Tropika 4(2):77-81.

Kartikaningtyas D, Setyaji T, Nirsatmanto A. 2017. Volume tegakan Acacia mangium pada uji perolehan genetik dengan kerapatan tegakan tinggi. Jurnal Pemuliaan Tanaman Hutan 11(2):113-122.

Lubis DS, Hanafiah AS, Sembiring M. 2015. Pengaruh ph terhadap pembentukan bintil akar, serapan hara $\mathrm{N}$, $\mathrm{P}$ dan produksi tanaman pada beberapa varietas kedelai pada tanah inseptol di rumah kasa. Jurnal Online Agroteknologi 3(3):1111-1115.

Muhajir, Muslimin, Umar H. 2015. Pertumbuhan semai jati (Tectona grandis L.f) pada perbandingan media tanah dan pupuk organik limbah kulit kakao. Warta Rimba 3(2):80-87.

Muharam, Saefudin A. 2016. Pengaruh berbagai pembenah tanah terhadap pertumbuhan dan populasi tanaman padi sawah (Oryza sativa L) varietas dendang di tanah salin sawah bukaan baru. Jurnal Agrotek Indonesia 1(2):141-150.

Prasetya B, Kurniawan S, Febrianingsih M. 2009. Pengaruh dosis dan frekuensi pupuk cair terhadap serapan $\mathrm{N}$ dan pertumbuhan sawi (Brassica juncea L.) pada entisol. Agritek. 17(5):1022-1029.

Prayudyaningsih R. 2014. Pertumbuhan semai Alstonia scholaris, Acacia auriculiformis dan Muntingia calabura yang diinokulasikan fungi mikoriza arbuskula pada media bekas tambang kapur. Jurnal Penelitian Kehutanan Wallacea 3(1):13-23.
Putra HF, Sulistijorini, Aryanti NS. 2017. Landscape function of post tin-mining land after reclamation in Bangka, Indonesia. Earth and Environmental Science 58:1-7.doi:10.1088/1755-1315/58/1/012018.

Setiadi Y, Adinda. 2013. Evaluasi pertumbuhan pohon di lokasi revegetasi lahan pasca tambang PT. Vale Indonesia Tbk. Sorowako, Sulawei Selatan. Jurnal Silvikultur Tropika 4(1):19-22.

Wasis B, Andika A. 2017. Growth reponse of mahagony eedling (Swietenia macrophylla King.) to addition of coconut shell charcoal and compost on ex-sand mining site of West Java Province in Indonesia. Archive Agriculture of Environmental Science 2(3):238-243.

Wasis B, Fthia N. 2011. Pertumbuhan semai Gmelina dengan berbagai dosis pupuk kompos pada media tanah bekas tambang emas. JMHT. 18(1):29-33.

Wasis B, Itantini. 2013. Pengaruh pemberian arang tempurung kelapa dan kotoran sapi (bokashi) terhadap peningkatan pertumbuhan semai jabon (Anthocephalus cadamba Miq.) pada media tanam tailing tambang emas. Jurnal Silvikultur Tropika 4(2):82-87.

Wasis B, Ghaida SH, Winata B. 2019. Application of coconut shell charcoal and NPK fertilizer toward Acacia mangium growth on the soil of ex-limestone mining in Bogor, Indonesia. Archives of Agriculture and Environmental Science 4(1): 75-82.

White PJ, Broadley MR. 2003. Calcium in Plants. Annals of Botany 92:487-511.doi:10.1093/aob/mcg 164.

Yuliana AI, Sumarni T, Islami T. 2015. Application of bokashi and sunn hemp (Crotalaria juncea L.) to improve inorganic fertilizer efficiency on maize (Zea mays L.). Journal of Degraded and Mining Land Management 3(1):433-438. 